\title{
Changing nature and emerging patterns of domestic violence in global contexts: Dowry abuse and the transnational abandonment of wives in India
}

\author{
Sundari Anitha, Harshita Yalamarty and Anupama Roy \\ (Accepted for publication in Women's Studies International Forum) \\ Corresponding author: Dr Sundari Anitha, \\ Reader in Criminology, School of Social and Political Sciences \\ University of Lincoln, Lincoln LN6 7TS \\ Email: sanitha@lincoln.ac.uk
}

\section{Abstract:}

This paper argues for the need to understand dowry-related abuse through a lens that focuses not only on micro-and meso-level gendered socio-cultural milieus and economic norms but also on macro-level formal-legal structures and global power asymmetries. Based on lifehistory narratives of 57 women in India and 21 practitioner interviews, this paper documents a growing phenomenon whereby men who are resident in another country abuse their Indianorigin wives, appropriate their dowry and abandon them. While dowry-related abuse in such marriages is part of a continuum of domestic violence prevalent in South Asia and the South Asian diaspora, we explore how gender and migration intersect to exacerbate existing forms of violence against women and foster new forms of violence such as transnational abandonment. Gender-blind transnational formal-legal frameworks and gendered and transnational structural inequalities come together to construct transnational brides as ‘disposable women’ who can be abused, exploited and cast aside with impunity.

Keywords: domestic violence in India; financial abuse; dowry; transnational abandonment of wives; gendered migration 


\section{Introduction}

Media reports in India, corroborated by non-governmental organisations and government institutions, suggest a growing problem of abandonment of wives by Indian-origin men domiciled in another country (Gupta, 2016). Based on the extent and nature of calls from transnationally abandoned women who contact Southall Black Sisters (SBS) ${ }^{1}$ in the UK, its Director, Pragna Patel delineates three main forms of abandonment: (i) a woman, migrating after marriage to her Indian-origin husband's country of residence, may be ousted or (less commonly) flee after a period of abuse; (ii) a woman who has migrated with her husband after marriage may be deceived into visiting India and abandoned there, while her husband returns and revokes her visa; (iii) a woman may be left behind with her in-laws in India after marriage while her husband goes back with assurances that he will sponsor her visa, but the woman is eventually ousted from their home or leaves because of domestic violence.

In 2008, the Indian government nominated the National Commission for Woman (NCW) to respond to issues pertaining to Non-Resident Indian (NRI) ${ }^{2}$ marriages. Government estimates have suggested that this problem affects approximately 20,000 women in total (NCW, undated: 1), though the basis on which such estimates have been made is not clear. ${ }^{3}$ What is evident from media reports (Gupta, 2016), women’s organisations in the West (Dasgupta and Rudra, 2009) and research in India (Jabbi, 2005) is that this is a growing problem. However, little is known about the nature of this problem and women's experiences during and following the process of abandonment, as there has been scant research on this subject, especially one which brings forth the voices and perspectives of abandoned women.

This paper explores the experiences of 57 transnationally abandoned women from the states of Punjab, Delhi and Gujarat in India. While neglect, emotional, verbal, financial and physical violence, sexual violence by husband or his relatives and denial of reproductive rights were recurring themes in transnational marriages and are discussed elsewhere (Anitha et al., 2018), 
our focus here is on the particular manifestations and impacts of dowry-related abuse in the context of transnational marriage and abandonment.

\section{Dowry and Domestic Violence in India}

In the context of India, dowry has been recognised as a key factor that underpins domestic violence-both among affluent families where dowry expectations are high (Bloch and Rao, 2002) and for women from poorer families unable to fulfil dowry demands (Srinivasan and Bedi, 2007). Dowry has also been implicated in other forms of gender-based violence such as sex-selective abortions (Sen, 2003). Traditionally a wedding gift given by upper caste Hindu parents in North India to daughters as part of a strategy for hypergamy, dowry is an aspect of marriage transactions and capital accumulation in other parts of the world as well (Srinivasan, 2005). Dowry can take the form of jewellery, cash, consumer goods or property provided by the family of the bride to that of the groom as a condition of the marriage at the time of and after the wedding. It has become a near-universal phenomenon among different Hindu castes and Sikhs, and has spread to other hitherto non-practicing communities, including Muslims and Christians. Research also documents the prevalence (Bhopal, 2009; Biao, 2005, Menski, 1998) and changing forms of dowry in the process of migration and settlement of Indian-origin diaspora in the adopted country (Bhachu 1985; Sheel, 2005). Media reports in the UK and Australia have recently documented the prevalence of dowry-related abuse (Amara, 2014; Jones, 2017). Even though the giving and taking of dowry is prohibited in India under the Dowry Prohibition Act 1961 and subsequently by Sections 304B and 498A of the Indian Penal Code, it remains a common practice. Stridhan - gifts given voluntarily to the bride by her parents and relatives - is recognised in law as a woman's personal property over which she has inalienable rights, though in practice it is controlled by the husband and his parents.

However, not all women experience dowry as a repressive practice and some may consider dowry a rightful share of their parents' wealth in a context where daughters do not commonly 
inherit property. Recent scholarship disassociates the presumed automatic causal link between dowry and domestic violence by emphasising that the giving of dowry does not always result in domestic violence, and not all domestic violence is related to dowry-demands (Bradley et al., 2009). However, this scholarship recognises the significance of dowry-related domestic violence and problematises dowry even in cases where there is an absence of any associated violence, as the practice of dowry simultaneously reflects and reinforces the devaluation of women. Extending Stark's (2007) concept of coercive control to the context of violence against women in India, Gangoli and Rew (2011) argue that patriarchal gender relations within society and marriage norms such as patrilocality and women's subordinate status as new brides create a 'conducive context' (Kelly, 2016) for abusive behaviour by female in-laws.

\section{Anti-dowry movement in India}

Through the anti-dowry movement in the 1980s, women's organisations in India succeeded in bringing out the violence hidden within the family and the home out into the public, foregrounding women's vulnerability arising out of their powerlessness and making dowryrelated violence a matter of public concern. One of the many creative strategies used by the women's groups in Delhi and surrounding areas included street plays, performed in front of the houses where dowry deaths had taken place to publicly shame known perpetrators. The movement succeeded in catalysing into existence Section 498A (1983) and Section 304B (1986) of the Indian Penal Code to tackle cruelty against women with regard to dowry demands and dowry deaths, respectively. Up until 1983, there were no specific provisions that addressed violence within the home. Thereafter, husbands could be convicted under the criminal charges of murder, abetment to suicide, as well as causing hurt and wrongful confinement.

The problem, however, was that violence within the home was being singularly attributed to the issue of dowry, which needed to be understood as a symptom rather than a cause. Flavia Agnes (1992, p. WS-25) cautions against pinning the blame for all forms of violence against 
women and girls — from female foeticide, infanticide to domestic violence - to the practice of dowry. She argues that though the initial demand by women's groups focused on laws to prevent dowry-related violence, this ultimately proved to be inadequate for the task of dealing with wider domestic violence (Agnes, 1992). Even as the clause defining cruelty under Section 498A was picked up by activists to address myriad kinds of violence, the vague definition of cruelty was interpreted by the police in such a way that a woman had to endure a very high threshold of violent conduct to be able to access the law (Jaising, 2009, p. 51). ${ }^{4}$ One of the effects of such a lacuna in the legislation was that women who went to file complaints of domestic abuse were often made to connect their complaint with dowry in some way, in order to be eligible to file a complaint under Section 498A or Section 304B, thereby sometimes undermining he credibility of their complaint (Agnes, 1992, WS-25). The spectacular and gruesome nature of dowry deaths and bride-burnings overshadowed from view the more 'mundane' and everyday kinds of abuse that women faced at home. Based on these understandings and a concerted campaign by women's groups, the Protection of Women from Domestic Violence Act (PWDVA) was passed in 2005. The PWDVA expands existing definitions of domestic violence to include "verbal, emotional, sexual, and economic abuse, and allows women civil and/or criminal redress for violations of the Act” (Lawyers' Collective, 2012). It represents a comprehensive framework in India to address the issue of domestic violence through institutional provisions, and marks the first acknowledgement by the Indian state of the forms of violence experienced within the domestic sphere, other than dowry deaths. In our own research, we have seen that dowry-related violence figures as a significant component of the spectrum of violence faced by women abandoned in transnational marriages and sections 498A and 304B of the IPC are crucial legal tools utilised by women, practitioners and lawyers in seeking justice. Within the structure of transnational marriages, the perceived high status and opportunities for upward and outward mobility presented by NRI grooms leads 
to newer and particular kinds of dowry demands. Our research explores how dowry-related violence becomes particularly magnified as it 'travels' on a transnational scale, as women are especially disempowered and dispossessed by gendered and global hierarchies of power as well as the nature of formal-legal systems, and allows us to further investigate the new and altered contexts of this violence in a transnational marriage.

\section{Research Methods}

The aim of this study — conducted in 2013-2016-was to understand the problem of transnational abandonment of wives in the Indian states of Delhi, Punjab and Gujarat, which have a long and diverse history of out-migration going back to the period of British colonial rule in India. The research aimed to understand the nature and impact of neglect, abuse and abandonment and document women's experience of help-seeking and services. Additionally, a key objective of the research was to stimulate policy debates to address this problem. Ethical approval was obtained from the relevant ethics committee at the University of Lincoln.

A combination of a convenience and snowball sampling was utilised to access abandoned women, combined with a purposive sample of key informants. Most women who participated in this research were accessed through police, the Gujarat State Commission for Women, women's groups and lawyers working with abandoned women. A few research participants told us about other potential participants, whose details were passed on to us after they had agreed to be contacted by us. Life-history interviews were conducted with a total of 57 women. This method enabled research participants to talk about their lives as a whole and enabled us to contextualise their marriage decision, the nature of their relationship with their husband and in-laws as well as the impact of the abandonment in the context of broader power relations, opportunities and constraints that shaped their lives. The interviews, which lasted between one to three hours, were transcribed verbatim where women gave permission to record them. In the few cases where such permission was not given, notes were taken and typed up soon after the 
interview. The aim was not to seek a representative sample but instead to undertake an in-depth exploration of women's experiences. Semi-structured interviews were also conducted with 21 representatives of community and women's organisations, police and lawyers specialising in abandoned women's casework, in order to gather practitioner perspectives on the nature of this problem, their practice responses to it and recommendations. All but one of these interviews were conducted with practitioners in Gujarat, Punjab and Delhi, while one interview was conducted with the Director of Southall Black Sisters (SBS) - who waived her right to anonymity. This paper is primarily based on the voices of the survivors, whose names have been anonymised in keeping with regional and religious naming conventions.

A limitation of this study relates to its reach. Apart from the few research participants who were accessed through snowball sampling, most women were accessed through police, women's/community organisations and lawyers. This research has therefore managed to reach very few women who have not sought help from formal sources of support, perhaps due to stigma, lack of resources, or indeed unfamiliarity with criminal justice processes. However, as one of the first systematic studies on this topic, this research has significant implications for our understanding of this emerging form of violence against women and for future research.

A grounded theory approach to data analysis entailed a process of continuous coding of each transcript to identify emerging themes, following which the coded transcripts were compared to identify recurring themes, thereby enabling us to trace similarities and differences between accounts. Riessman (2008) argues that the interpretive approach of narrative analysis is very well suited to studying identities as well as 'critical life events'. The key features of this approach include identification of key events in the life story with particular attention to temporality and sequence of events; the causality attributed to different events and the connection/link participants attribute to these events; the structure of the narrative; exploration of what particular life-events meant for the participant at the time as well as what they means 
at the time of the interview; and the agency of the participant within their story and the sociocultural context of the story. Such an approach enables individual narratives to be situated within particular contexts, alerts the researcher to the broader socio-cultural context of the narrative (Riessman, 2008) and to the structural preconditions of personal experience.

\section{Abuse and abandonment in transnational marriages by men of Indian origin}

Twenty-eight of the 57 women interviewed for this research had been married to Indian-origin men resident in the UK, eight of the Indian-origin husbands were from Italy, while four each from Australia and USA and the remaining 13 were from a range of other countries. The women belonged to a range of castes, which indicates the prevalence of transnational marriages and abandonment across the caste-hierarchies. A majority of our sample were university educated (69\%) and unemployed (54\%). The over-representation of highly educated, middleclass women in our sample could reflect the social class of women marrying NRIs, because of the large dowries involved. It could also reflect the ways in which we accessed our sample through lawyers and police, as those with financial resources and social capital are more likely to access these agencies. Women who participated in this research were from both rural areas and cities. Where women had educational qualifications and lived in a city, they were more likely to be employed. It was not possible to find out the educational background or jobs of the husbands, as many women—including marriage migrants—were not aware of these details. Twenty-three women — just over a third of the research participants-migrated following marriage. In the context of ongoing and escalating violence, these women were deceptively taken back to India and abandoned there or less commonly, left the marital home to escape the abuse and were prevented from returning. Just under two-thirds of the women we interviewed never migrated following their marriage. Following a speedily arranged marriage and exchange of dowry, the husband would depart for his country of residence, leaving his wife to live with her in-laws, in keeping with socio-cultural norms in India. The expectation was that he would 
apply for a spouse visa to enable her to join him, a process that can take months. While she waited for the visa, he would communicate with her, and might visit on holidays, but eventually the communication would fade away. During this period, she was responsible for domestic labour and caring for her in-laws, who would also demand ongoing dowry transfers from her parents. Eventually, she was cast out of the affinal home or left, following escalating violence. Common to both categories of women, ex-parte divorce proceedings were initiated by the husband in his country of residence, often without the woman's knowledge or consent.

\section{Socio-cultural and economic landscapes of the transnational arranged marriage: Gendered expectations about dowry and wedding expenses}

There are a number of contexts within which transnational marriages may be preferred by the groom and the bride and their families. In a context where material culture and middle class consumption in India is increasingly globalised, at least in large metropolis, global hierarchies of places underpinned by social and economic constructs of 'development' and 'modernity' have become central to the construction of a desirable partner in an arranged marriage.

Reflecting the direction of the labour-migration flows, the West has also come to be the ideal destination of transnational marriage-scapes, with women availing gendered opportunities for mobility by marrying out from countries in the Global South and more recently Eastern Europe and former Soviet Union to countries in Western Europe, America and to Australia (Constable, 2005; Palriwala and Uberoi, 2008). The direction of this flow also mirrors gendered norms about hypergamy, whereby women marry 'up' the transnational hierarchy-a process that Constable $(2005,15)$ terms ‘spatial hypergamy’. Such marriages also enhance women’s status within their natal families, open up routes to future migration of kin and may enable them to realise aspirations of social mobility (Chaudhuri et al, 2014, Mooney, 2006). For communities with a strong history and culture of migration and given the tighter immigration controls in many countries in the West, transnational marriage remains one of the few viable routes for 
migration. In her review of cross-border marriages, Constable $(2005,4)$ explores how these marriage-scapes are simultaneously shaped and limited by existing and emerging cultural, social, historical and political-economic factors-what Mahler and Pessar $(2001,5)$ term the 'gendered geographies of power'.

However, economic motivations cannot on their own explain the desirability of transnational marriages for both the bride and the groom. The role of emotions and social connections - as represented by obligations to kinship or wider social networks and the desire to maintain connections to ancestral homelands through marriage mean that such marriages can also be understood as part of broader transnational relationships and socially grounded processes imbued with thick cultural meaning (Walton-Roberts 2003: 236). Walton-Roberts (2003: 245) suggests that for South Asians in the UK, such arranged marriages may represent the prospect of maintaining a connection to the homeland, as a 'traditional' wife from India is perceived to play a central role in community formation. Such marriage choices also reflect and are propelled by popular imaginings about gender, sexuality, tradition and modernity (see Constable, 2005). Stereotypes of Indian-origin women as accustomed to gendered inequities may also play a role in making such marriages attractive to men living in the West, who may anticipate that they will be able to assert themselves in their relationship or encounter minimal resistance to the gendered division of household labour whilst expecting women to undertake paid work. Transnational marriages may appeal to women for a different set of reasons: based on dominant constructions of the West and the NRI, women may hope for a more equitable relationship and the opportunity to join the labour market, while nuclear living arrangements may offer the potential of escaping the subordinate status accorded to new brides within a joint family set-up and of establishing an intimate relationship with the husband free from constraints imposed by the mother-in-law. Underpinning the tension between men and women's contradictory imaginings about the ideal partner and marriage are diverse 
constructions of national and transnational subjects that lie at the intersection of discourses about gender, capital and desire.

The asymmetries between the bride-givers and bride-takers (Banerjee, 1999; Dube, 2001) are exacerbated by global hierarchies between nations, gendered citizenship and gendered economic opportunities and classed constructions of masculinity which come together to make the NRI man a highly marriageable category in the political economy of arranged marriages (Kalpagam, 2005; Sheel, 2005). This is evident in the newspaper advertisements for matrimonial partners, where apart from the common categories of caste (jati) and religion, separate sections are devoted to NRIs. These hierarchies are central to dowry expectations. Voigt-Graf (2004, p. 33) notes how the amount of dowry is commonly calibrated not only according to the NRI's social status and job, but also in accordance with the place his country of residence occupies in the hierarchy of nations-NRIs from the US could expect larger dowries than those from Australia. All the women we interviewed confirmed that the giving of dowry was central to the marriage, either as an explicit demand or an implicit expectation.

A common factor in marriage negotiations was a secrecy and haste on the part of the bride's family, lest a better prospective bride come to the attention of the NRI groom's family. It was common for the gap between proposal and marriage to be as little as a couple of weeks, with a few marriages taking place within 2-4 days of the proposal. In all the cases, and in conformity to social norms, it was the men and their family who 'chose' the women by initiating a proposal. In most cases the men were aware of the limited options available to women, particularly where women were disadvantaged because this was a second marriage or had younger unmarried sisters whose marriage prospects would be affected by the breakdown of her marriage. Shiva, a middle class, highly educated woman who was divorced and perceived to be 'too dark complexioned', faced difficulties securing a match. When approached by an NRI from London, her family agreed immediately, and wedding took place a few days later: 
The family was good. When I talked to him he said he was a vegetarian and had no other addictions. However, I was not inclined to immediately say 'yes' to him. But the elders insisted, so within two days the betrothal ceremony was performed and on the twelfth day the wedding ceremony took place. (Shiva, 29)

The groom's family often contrived this hasty marriage by informing the bride's family that he was in India for a brief holiday, during which they expected the marriage to be solemnised. Such constraints severely limit the temporal and spatial opportunities for the bride's family to conduct enquiries about the prospective groom. Many women and their families were not aware of fundamental facts about the groom such as his job, income, visa/passport status, address or marital history. It was only upon abandonment that some women discovered that this was the second or third such transnational marriage and abandonment by the husband.

In a majority of cases, demands for additional dowry were made after the wedding date had been publicly declared, a period when the cancellation of the wedding would bring shame and dishonour to the bride and her family. In most cases, parents struggled to meet these demands in the hope that this would ensure the future happiness of their daughter.

When the marriage was fixed they started demanding more and more [dowry]. It was the first wedding in our family - I have six younger sisters. My family felt pressurised, because if the older daughter's marriage is called off then it will be bad for the younger ones. Who will marry them? So my father agreed to their demands. Whatever they laid their hands on, whatever they saw, they wanted it-like a TV with home theatre, furniture of their choice. (Kiranpreet, 35) Alongside a large dowry was the equally problematic expectation of a carefully orchestrated and suitably lavish wedding ceremony, hosted and paid for by the bride’s family. The wedding reception commonly catered for over 500 people (1500 was the most we encountered). A themed specialist wedding venue, meat dishes and a free bar in keeping with what was presented as a Western wedding convention, were common demands: 
First we had seen a slightly less expensive palace. Then the in-laws said, 'Our relatives are coming from abroad, so this won't do'. At their insistence we booked this expensive farmhouse because it could hold a bigger gathering. (Sharanjit, 28)

One woman from an upper caste, middle class family in Delhi reported how the wedding venue had to be altered at short notice to meet the expectations voiced by the groom's family: My father-in-law, he put the marriage 'on hold'. The wedding venue was changed four times, each time to a more costly place. He wanted a fleet of cars, fancy arrangements for his son. He told my parents, 'We are high class people compared to you'. [...] He was furious because arrangements weren't made for a grand reception at the airport to welcome them. (Gauri, 26) Non-reciprocal gift-giving by the bride’s family to the groom's extended family escalated the wedding costs to between Rs.10-15 lakhs (£10,000-£15,000), which represented several years’ savings or a loan for most families. Satinder's wedding expenses stretched the financial capabilities of her lower middle-class family, but as she was the only daughter, her parents capitulated to the escalating demands of the groom's family.

They had asked us for a grand, lavish wedding. They said, 'We don't want anything else, just a good wedding'. When the date drew near, we got to know indirectly from our relatives that they wanted other things as well, because otherwise their relatives would say that the daughter in law didn't bring anything for the house. In Punjabi culture, we call it 'stridhan' because we can't say dowry officially, the girl's family gives gifts. Like sofa, almirahs, washing machine. We booked a big resort for the wedding, so it was all quite expensive. We gave gold to all his family. Earrings for the women and jewellery for all the extended relatives. We gave them furniture for the entire house, and we gave clothes to everyone. All in all, it was more than Rs. 8 lakhs [£8000]. (Satinder 34)

While the disproportionate burden of wedding expenses and the giving of dowry are common features of most arranged marriages in India, there were also specific aspects of transnational 
marriages that exacerbated these gendered inequities. These included the constrained opportunities to enquire about the groom and his family which would otherwise be a routine aspect of arranged marriage negotiations.

\section{Ongoing dowry demands and dowry-related violence following marriage}

Following the wedding, the amount of dowry she brings often defines the new bride's position within the family. Women recounted expectations or demands for transfers of wealth and gifts from the bride's family in the days, months and years following the marriage. Dowry demands were part of the context — though not the only one-within which women experienced various forms of domestic violence from the husband and the in-laws. Apart from dowry-related violence, women recounted experiencing a range of abusive behaviours including domestic servitude. Of the 57 women who participated in this study, all women recounted coercive and controlling behaviour by their husbands, in-laws or both, while 42 recounted physical violence from husband and/or in-laws. Violation of women's sexual and reproductive rights was also common: a third of the women disclosed sexual violence perpetrated by their husband, a quarter disclosed sexual violence from other male in-laws and 11 women were coerced into having abortions (Anitha et al., 2018, p. 755). So women’s experiences of dowry-related violence need to be located within this broader continuum of abuse (Kelly, 1988), whilst examining the specific manifestations, features and the impact of this abuse in transnational marriages which end in the abandonment of wives.

Most women reported that their parents initially tried to meet the dowry demands as they hoped that their daughter would have a secure life once she migrated and joined her husband. A woman belonging to a lower caste, who lived in a smaller town in Punjab, told us:

My father used to bring something every time he came to see me. We have a sweetshop, so they [in-laws] would routinely order bottles of cold drinks, sweets, to beu delivered to their place 
from our shop. My brother or father would come by in the evening, and they always had some demand or the other, we want this, that, this, that. All the time. (Kiranpreet, 35)

The men and their families exploited their knowledge of the limited options available to women for whom the end of the marriage would bring considerable stigma. In some cases, sponsorship to the husband's country was used as a bargaining chip to extract further dowry payments: They never asked for dowry during the five days between our meeting and the wedding, and he returned to the UK shortly after the wedding. Soon after that his parents began taunting and abusing me saying that they had received marriage offers with Rs. 3 crores [£300,000] dowry for their son yet they had brought me into the family with nothing. It was the second marriage for both of us. But they blackmailed me saying, 'It's your second marriage, where will you go, you have to bring in the money’. (Gita, 29)

When Gita's family could not meet their demands, her husband cancelled his application to sponsor her to the UK to join him and his parents threw her out of their home two months after the wedding. Unfortunately for her, this happened just a week after she had resigned from her job at their insistence, leaving her in a financially precarious position. A few women who were left behind with their in-laws while their husband returned to his country of residence reported that the sponsorship process was utilised to extract further dowry from them:

My in laws asked for 10 lakhs [£10,000] to file an application for my visa. My parents managed to raise 5 lakhs [£5,000], but my in-laws dropped me off at my parents' house and told them that I had to stay there till they gave the rest. It was only after nine months that my parents managed to raise the rest of the money and I could go back. (Radha, 24)

While deception was a common means of securing additional dowry payments in the first few months following the wedding, consistent with other research findings (Bloch \& Rao, 2002), threats were also utilised purposefully and strategically to extract dowry payments. For Sharanjit, the threats began just three months after the wedding: 
He started threatening me, saying, 'Give me Rs.20 lakhs [£20,000] to open a restaurant here, then I will bring you to Germany. Otherwise I will divorce you’. (Sharanjit, 28)

A few women women recounted their attempts at answering back when faced with verbal abuse and regular taunts directed at them for not bringing enough dowry:

My mother-in-law used to say, 'Do you know, in our village dominated by Patels, what is the price of an NRI son-in-law?' I would respond, 'How would I know what the going rate is?' When I answered back, that made them angry and they used to beat me with whatever was at hand. My sister-in-law's two children used to join in beating me. (Bhavi, 50)

Though dowry demands were not the only context for domestic violence in these transnational marriages, they were a significant part of a matrix of abuse and exploitation of the women that can be attributed to the exacerbation of gender inequalities through global hierarchies of power. While the giving of dowry and the continued expectation on part of the husband/his family of gifts from the bride's family are part of most marriage arrangements, it could be argued that extraction of dowry was the primary purpose of a small minority of transnational marriages, and one of the key factors in the abandonment. As one lawyer stated:

Some people have made a business out of this. They come today, marry a girl and take dowry from her. They go to their country, there is violence and abuse of the woman, and they get divorced. Then they come back to India and again there is another woman. There are a lot of cases like this where the grooms have been caught while marrying for the second time. This is like a side business for them to earn money. (a lawyer in a small town in Punjab)

This systematic and purposeful dowry abuse takes place in a context where few other aspects of a genuine marriage are realised, and where it is not intended that the couple will ever build a life together. In several marriages, there was a dimension of collective organisation that involved the immediate and in some cases extended family of the groom as perpetrators, or at least complicit in the process. Meticulous planning and careful strategising enabled men's 
families to secure a dowry without incurring even the minimal costs that have to be met by a groom's family in a wedding. One woman, who lived in a village in Punjab and is one of six sisters, recounted the deceptive circumstances of the wedding:

My aunt found the match. They came to India and within a few days the marriage was fixed. They asked us to arrange the wedding quickly. We asked them to give us at least 15 days, but they were insistent, as he needed to go back. Our relatives agreed and the wedding took place within three days. We had to organize everything in a rush. There were no relatives from their side of the family — no music, no baraat [wedding procession of groom's family and friends which arrives at the bride's place for the wedding], no celebration from their side. There were just the immediate family members. They told us that they had arranged a party back home [in their native village in Punjab], but when I went there after the wedding I realised that nobody in their village knew that he has gone to get married. There is a custom that takes place on the second day after the wedding, they didn't invite my elder sister for that custom. [..] And right after the wedding — the day after — their demands for dowry started. (Parminder, 28) Over the coming months Parminder's in-laws harassed her for more dowry and she eventually returned to her natal home. After a few months, she made her way to her husband's country of residence to save her marriage but faced domestic violence, and eventually returned home and is now seeking the return of her dowry through the legal process. Though Parminder's aunt arranged the marriage, Parminder did not think she was complicit in the abuse.

In some marriages, the immediate family of the groom was resident in another country and fled India with the dowry soon after the marriage. Another woman from a lower middle class family in a small town in Gujarat reported:

He contacted us in response to an [matrimonial] advert my father had placed in a newspaper. He was good looking, had a good job in a hotel in a Gulf state, so we decided to proceed. Their main condition was that the wedding would have to take place in their native town because his 
mother was too ill to travel-my dad was a bit hesitant but they said they would host the ceremony [a highly unusual offer in a context where the bride's family hosts and pays for the wedding]. So we agreed. When we reached the groom's house with our extended family, we did not see any sign of celebrations. They informed us that their uncle was on his death bed, he could die any day now. It would have to be a simple affair, out of respect for him. So, next day, we went to a temple and performed the ceremony, and I moved into my husband's place. Even the neighbours did not know about our marriage! I later found out from the neighbours that he had married twice earlier under similar circumstances. He soon left India and his sister-inlaw took the gold that I got as dowry-since there were no wedding expenses, my parents had given me a dowry that was larger than would have otherwise been the case (Arti, 36).

This form of dowry-related abuse seems to be unique to transnational marriages. The temporal and spatial constraints which prevent the bride's family from pursuing the groom (and his family) for justice across national borders create particular contexts for such abuse.

In most cases however, dowry abuse occurred within the normative framework of a maritalthough abusive-relationship and women initially tolerated it so long as they felt they could "adjust" or compromise to make the relationship work, as the socio-cultural norms against divorce prevented women from seeking help or acting to end the relationship. But for most women, there came a time when the increasing dowry demands could not be met and the violence began to be considered unbearable. For marriage migrants, however, the added vulnerabilities arising from insecure immigration status limited their options.

He said, 'I have these papers ready, I want to marry someone else, I want nothing to do with you or your son. You both leave, or you ask your brother to give me 25 lakhs [£25,000]. If you want to stay with me then get me the money, else I will send you both back'. (Satinder, 34) Men and their families were aware of, and exploited the immigration policies of their country of residence, which rendered women dependent upon their abusive partners. Women who 
migrated upon marriage recounted how men weaponised - women's insecure immigration status to threaten them with deportation. Some countries such as the UK, Canada and the USA have policies that entitle immigrant women who experience domestic violence to leave their abusive partners and apply for the leave to remain in the country. However, none of the marriage migrants were aware of their rights. In the context of rights granted to immigrant spouses in countries such as the UK, men utilised the restrictive immigration policies that operate across transnational spaces—including specific policy climates intended to create a 'hostile environment' for immigrants such as that in the UK since 2010 (McVeigh, 2018)—to treat their wives as disposable women. As one woman from Gujarat recounted:

He often used to hit me. He'd tell me that he had better girls to choose from... that he could get a better dowry. After three years like this, we came to India for a holiday. After two to three days, he left me at my mother's place. We had return tickets-we were planning to go back together after two months. But he phoned me and told me that he had to return to the UK that very night. We all went to the airport to see him off. Later on, he suggested that I stay on to attend English classes for some exams that I was planning to take in the UK, so I extended my ticket. It was only later that I realised that he was waiting for my visa to expire. As soon as the deadline passed, he called to say he was divorcing me. (Hira, 32)

Once the men had managed to abandon the women in India, they would commonly revoke women's visas or initiate divorce proceedings. Women were prevented by immigration authorities from returning to their husband's country of residence to participate in civil or criminal court proceedings. The immigration policies and practices thus served to exacerbate men’s control and create a 'conducive context' (Kelly, 2016) for such abuse.

Palriwala and Uberoi (2008, p. xviii) argue that dowry in transnational marriages serves to subsidise global capital. The practice of dowry has been linked with the creation of a cheap and flexible global labour force of IT professionals for whom dowry payments constitute a 
fluid fund that can be used to directly finance men's migration process (Biao, 2005). Some research participants reported that their dowry was used to fund men's further education or business ventures abroad, as discussed above by Sharanjit, the eldest of three siblings, who was well educated and from a middle class family in Punjab. Once the men completed their studies/established themselves and were entitled to secure immigration status, and often when no further dowry transfers were forthcoming, they initiated divorce proceedings.

Of the 23 research participants who migrated upon marriage, sixteen were taken back to India and abandoned and their visa revoked, thus depriving them of their right to be represented in any divorce proceedings, to claim financial settlement, or secure the return of dowry. The remaining marriage migrants were thrown out of their marital homes or fled to escape the violence and eventually made their way back to their natal families in India, unaware of the provisions in their husband's country of residence that could have enabled some women to gain residence rights there. A majority of women who were left with their in-laws while they waited for the sponsorship documents gradually realised that their husband and his family had no such plans for them; and that the purpose of the marriage was to secure dowry and domestic labour for the in-laws' household. The period between the marriage and the abandonment varied vastly, with some women being abandoned following appropriation of their dowry within two weeks of the wedding, while a few women who were left with their in-laws remained there for up to eight years before being cast out or leaving because of the violence. Most women's marriages lasted between two to three years.

\section{Surviving abandonment: Seeking the return of their dowry}

Following abandonment, ex-parte divorce was commonly initiated by the husband, in a context where the woman was ignorant of the proceedings or could not represent herself in legal proceedings in another country (Bhattacharjee, 2013). Abandonment across transnational borders meant that women were refused visas to return to their husbands’ country of residence, 
thus rendering them unable to initiate any criminal or civil proceedings against the men for domestic violence, to claim the rights to settlement that they were entitled to in some countries and to access their legal rights to a financial settlement and child support payments. Following their abandonment, women reported a loss of relationships with extended family and friends, detrimental impact on the social standing of their family, difficulty in securing employment for themselves and a loss of good marriage prospects of younger sisters. In a context where marriage remains the primary marker of social status and identity for women, abandoned women had limited means of living independently or undertaking paid work, particularly in rural areas; and faced social stigma, poverty and the risk of destitution.

Most women first resorted to family mediation, failing which they involved local community leaders such as their panchayat (local self-government representatives) to put pressure on the men's families if they were in India. It was upon the failure of all these informal and semiformal mechanisms, or where the men and their families were out of reach that some of the women initiated legal action in India against their husbands and in-laws to recover their dowry and seek a financial settlement. In four cases, police intervention served to re-orient—at least to some extent — the power imbalance between the two families.

I went to the police station. The marks of beatings were fresh and visible on my body. So, the complaint was registered under section 498A of the Domestic Violence Act. We eventually arrived at a compromise, and they gave me Rs. 15 lakh [£15,000]. I have put some in a fixed deposit for my son, and the interest helps us meet our household expenses. (Okhaben, 42)

Four women successfully used the legislation on domestic violence and dowry to register police cases against their husbands and/or in-laws and secured a financial settlement or the return of some of their dowry which enabled them to secure their future. However in most cases, the police were reluctant to use the two main laws pertaining to domestic violence and dowry in India, section 498A and section 304B, unless it was related to a dowry claim or where women 
experienced grave physical violence. In the absence of tangible evidence of severe physical injury, and sometimes despite a history of such violence, many women reported that the police remained reluctant to file the FIR. ${ }^{5}$ We did not encounter any women who had accessed the provisions under the PWDVA to seek redress for the domestic violence they had faced; neither did police officers, lawyers or practitioners mention the PWDVA as one of the tools available to women and their families. Perhaps this had to do with the relative newness of the law (at the time of interviews the law was under 10 years old); or rather that dowry remains one of the most widely used basis for claims of harassment, violence and dispossession by women and their families, and legal tools pre-dating the PWDVA are still closely associated with dowrybased claims. But successful dowry-related claims were hard to find-none of women we spoke to had managed to recover all of the dowry that had been given to the groom and his family.

Women also found that relative to their husband's family, they had comparably fewer financial resources, and as the plaintiff, they had to negotiate their way through the criminal justice system. This research does not indicate any caste-specificity to the prevalence of transnational abandonment. However, caste and class positions-and women's level of education in particular-had implications for women's engagement with services. For instance, Okhaben (above) belonged to an upper caste community. Women from lower castes or those whose families were poor or had little social standing who embarked on this route found the process time-consuming, expensive and disempowering.

First we consulted a lawyer, then we went to the police station, to the women's cell. It took a lot of time, even an FIR doesn't get registered quickly. I went many times, I used to go, and start crying, 'What stage is it in your enquiry? Have you registered an FIR?' I'd never seen a police station in my life and today I still have to go there, battle my way through it, why?! [...] 
The in-laws kept everything. I called them, saying, 'At least return my clothes!' They said, 'We have nothing of yours here’. (Jatinder, 30)

The NRI men and their families utilized strategies such as placing an advertisement in the newspaper with a declaration that the son had been disowned, or transferring the men's property to a sibling through backdated documents. The lawyers we interviewed confirmed that these were common practices that helped men and their families evade women's claims upon their property as they sought compensation for the loss of their dowry. For most women, there was no satisfactory resolution as the police would not register or pursue a case effectively or could not follow up on a case because the NRI and his family were domiciled abroad. In some cases the women attributed police inaction to bribery and corruption, as the in-laws had access to greater financial resources and remittances from their son, while women's parents were reluctant to use up scarce family resources after they had already lost so much.

I learnt from a neighbour that my husband had come to India to attend a wedding. I registered a complaint at the police station and he was arrested and his passport confiscated. But he bribed the police and got back his passport and left the country the very next day. (Bhavi, 50) The loss of dowry upon abandonment exacerbated women's difficulties, as they were perceived to be burdens on their natal family and at risk of domestic abuse from them. Returning to their parental home placed some women in a precarious position as a potential threat to the inheritance of their brothers. Since dowry is commonly perceived to be a form of pre-mortem inheritance for women, received upon marriage, women's return to their natal family was often perceived to create a threat for the brothers who feared that they might now have to share their inheritance with their sister. Though from an affluent and upper-caste family, Jasma recounted her difficult domestic circumstances after the loss of her substantial dowry: Things are not easy here-all I can say is that I stay here. But my brother tells me all the while that I should give him in writing that I have no share in my father's property. [...] My brother 
says he will look after me and get my daughter married if I renounce my share of the inheritance. Now, if I give up my right and in case my relations with my brother and his wife do not remain cordial, where will I go? (Jasma, 38)

While women are commonly denied their inheritance rights, there is a gendered social expectation that marriage will bring financial security to a marital family unit—and to the new bride-because of the dowry she brings. However, in the context of being abandoned, loss of dowry and of the affinal home combined with their insecure tenure in their natal home rendered abandoned women highly vulnerable to dispossession and violence.

A regional politician and ex-MP, who has worked to raise the profile of this issue in Punjab, told us that in his experience, abandonment in transnational marriages is akin to "an organised crime by a group consisting of the in-laws, who all come together to rob and exploit the woman. They all know what is going on in the marriage, that the woman will not be taken abroad, that she will be cheated.” For some men and their families such marriages seemed to be a relatively low-risk means of obtaining financial resources and/or domestic labour, with the women being treated as 'disposable' — to be cast aside when they had outlived their utility.

I found out later that he has done this to three women. If nothing happens to them, this is what they'll continue doing! They say, 'You can't do anything, we will not go for a settlement'. He has always threatened me, saying I was powerless. He would taunt me, 'Can you come all the way here [to the UK]? Can you reach me? Show me if you can'. Sometimes I think he was right about that. The law does not work for women like me, nothing can harm these men who are abroad, no one can get to them. (Jatinder, 30) Jatinder was at the end of her tether and was coming to the gradual realisation-like many other women we interviewed — that she had scarce means of securing justice. 


\section{Conclusion: Dowry as a form of financial abuse in transnational marriages}

Our study captured the incremental nature of violence which accumulates around dowry but is not restricted to it. For many women, female in-laws were often the primary or joint perpetrators of exploitation, abuse and abandonment. Violence by female in-laws remains somewhat neglected as the broader assumption of male-on-female violence informs much of the theorising on domestic violence, particularly in the West. Unlike domestic violence in the UK, where over 92\% of the perpetrators are men (Hester, 2009), research in South Asia indicates that between $33 \%$ to $40 \%$ of such violence is perpetrated by the wider household, including female in-laws (Panchanadeswaran \& Koverola, 2005; Ragavan \& Iyengar, 2017). There are multiple understandings of domestic violence in India-feminist conceptualisations frame it as male violence against women (Kapur \& Cossman, 1996; Bradley, et. al., 2009) or acknowledge the role of mothers-in-law in such acts, but subsume it within the category of the wider marital household (Panchanadeswaran \& Koverola, 2005), while legislative and legal discourses frame it as intra-relational conflict and power struggle between mother/sister-in-law and daughter-in-law, or dowry-related violence (Gangoli \& Rew, 2011). Feminists have analysed the role of wider family members including mothers-in-law in the context of the patriarchal interests it serves (Fernandez, 1997; Kandiyoti, 1988), arguing that domestic violence perpetrated by female in-laws can be conceptualised as a form of proxy (male) violence against women, not only because it serves male interests in dividing women, but also uses older women to control younger ones in the family (Kandiyoti, 1988; Fernandez 1997; Gangoli and Rew 2011). The concept of patriarchal bargain recognises the social and familial benefits that accrue to particular categories of women (mothers/sisters-in-law) who accept and are complicit in the exercise of abuse in these relationships, thereby upholding broader gendered power regimes whilst exercising some degree of power over other subordinate women (Kandiyoti, 1988). 
Though women's narratives recounted a continuum of violence, in their accounts about their efforts to secure redress the issue of dowry was overemphasised in keeping with the legal system's almost exclusive focus on dowry. Though the expansive definition of domestic abuse within the 2005 PWDVA in India can incorporate coercive and controlling behaviour, the normalisation of control within gendered hierarchies and in keeping with the new bride's subordinate status in the household means that only extreme forms of physical violence, where there is evidence of injury, seem to evoke any police or legal response. Our method of life history interviews were effective in eliciting a fuller account of the various forms of violence women were subjected to. However, our research also establishes that particular forms and manifestations of dowry abuse are specific to transnational marriages. This offers an original insight into how existing forms of violence against women can come to be reconfigured in accordance with 'what works' to bring benefits to men and their families in particular and changing contexts. Research on violence against women needs to be responsive to new and altered forms of violence in changing geopolitical and global contexts.

The findings from this study help us to reflect on four pivotal questions: how gender operates in transnational contexts; the reasons for this; what the effects of gender are across transnational spaces and processes; and the ideologies operative within them (Mahler and Pessar, 2001, p. 441). Attention to these questions requires us to consider how gender and migration intersect to exacerbate existing forms of violence against women and to create contexts for new forms of violence against women such as the transnational abandonment of wives. There are several local and transnational contexts that explain the abuse, exploitation and abandonment of wives. The inequalities within the institution of marriage are exacerbated by the geopolitical inequalities between nations, whereby the groom's family is able to command greater resources, mobility, knowledge of state institutions and legal mechanisms. Cultural practices and dominant social norms which make for patriarchal control and devaluation of women 
including dowry and patrilocality played an important role in the exploitation, abuse and abandonment that ensued in all the cases we documented. More crucially, the inadequacy of national and transnational legal mechanisms serve to construct transnational brides as particularly vulnerable to dowry-related abuse (Patel et al., 2016). Abuse in transnational marriages is rooted in and results in gendered devaluation of women and is enabled by genderblind policy frameworks which do not recognise transnational abandonment as a form of violence against women. There exist few national and transnational legal mechanisms through which women can secure equitable financial settlement upon divorce, seek the return of their dowry, seek maintenance for their children or indeed pursue other civil or criminal sanctions to redress their abuse and exploitation. Transnationally resident men are able to take advantage of this gap and regard transnational brides as an inferior class of citizens and as a category of women who can be exploited and disposed of with impunity.

Transnational marriage abandonment is an emerging and growing problem due to globalisation and increased flows of migration overlapping with marriage. This opens up transnational spaces within which perpetrators can commit, often with impunity, new forms of violence against women. The cross-jurisdictional nature of the phenomenon brings with it specific challenges in respect of protecting vulnerable women and children and safeguarding their fundamental rights and freedoms under international human rights law. To plug the 'justice gap' for women who have been unable to recover their dowries, the courts in various jurisdictions need to give proper recognition to the unique status of dowry and stridhan as women's property when addressing divorce and financial matters. But alongside the focus on dowry, there needs to be a broader recognition of transnational abandonment as a form of domestic violence, as this practice entails coercive and controlling behaviour that is intended to deliberately deprive a woman of her rights and results in a range of harms. 


\section{Footnotes:}

1. Southall Black Sisters (SBS) is a UK-based women's organisation which provides services for black and minority ethnic women and campaigns to end violence against women and girls.

2. A Non-Resident Indian (NRI) is a citizen of India who holds an Indian passport and has temporarily emigrated to another country. However, in popular parlance, NRI denotes any person of Indian origin who lives in another country, which is how this term is used here, reflecting the voices of the women and the practitioners interviewed for this study.

3. There has been no systematic research on the scale of this problem in India, but various estimates have been put forward by government agencies, media and NGOs. Dasgupta and Rudra (2009: 18) note that estimates range from 20,000 abandoned brides upwards. They quote India’s minister for Overseas Indian Affairs, Vayalar Ravi, who stated in 2008 that in Punjab alone, at least 20,000 legal cases were pending against NRI husbands, presumably for abandoning their wives. In 2009, National Commission for Women's (NCW) chairperson, Ms. Girija Vyas, commented that 'out of $10 \mathrm{NRI}$ marriages, two result in the wife being abandoned after honeymoon', a figure that has been repeated in the media (Gupta 2016; TOI 2009). It is not clear how these agencies have arrived at these figures.

4. Cruelty was defined to mean any wilful conduct which could have driven the woman to commit suicide - or caused grave injury to her or posed a danger to her life, limb or health (either mental or physical) (Jaising, 2009, p. 51).

5. A First Information Report or an FIR is the written complaint that is filed at the police station where the offence is reported by the victim or someone on his/her behalf.

Acknowledgements: The study on which this paper is based was funded by British Academy (PM120051), who had no involvement in the data analysis or the preparation of this article. We would like to thank Nalini Trivedi (AWAG) and Anjali Chahal for their help in collecting the data on which this paper is based. The authors have no competing interests to declare. 


\section{Bibliography}

Agnes, F. (1992) Protecting women against violence? Review of a decade of legislation 198089. Economic and Political Weekly 27(17), 19-33.

Amara, P. (2014) Shunned, beaten, burnt, raped: The dowry violence that shames Britain, The Independent, 17 October. Available at:

http://www.independent.co.uk/news/uk/crime/shunned-beaten-burnt-raped-the-dowryviolence-that-shames-britain-9803009.html (accessed 7 December 2017)

Anitha, S., Roy, A. and Yalamarty, H. (2018) Gender, migration and exclusionary citizenship regimes: conceptualizing transnational abandonment of wives as a form of violence against women, Violence Against Women 24 (7): 747-774.

Bhachu, P. (1985) Twice-migrants: East-African Sikh Settlers in Britain. London; New York: Tavistock Publications.

Bhattacharjee, S.S. (2013) Distance silences and default judgements: Access to justice for transnationally abandoned women, University of Pennsylvania Journal of Law and Social Change 16(1), 95-110.

Bhopal, K. (2009) Identity, empathy and 'otherness': Asian women, education and dowries in the UK, Race Ethnicity and Education 12(1): 27-39.

Biao, X. (2005) Gender, dowry and the migration system of Indian information technology professionals. Indian Journal of Gender Studies 12(2\&3), 357-380.

Bloch, F. and Rao, V. (2002) Terror as a bargaining instrument: A case study of dowry violence in rural India. American Economic Review 92, 1029-1043.

Bradley, E., Tomalin, E. and Subramaniam, M. (2009) (eds.) Dowry: Bridging the gap between theory and practice. London: Zed Books.

Chaudhuri, S, Morash, M. and Yingling, J. (2014) Marriage migration, Patriarchal bargains and wife abuse: A study of South Asian women, Violence Against Women 20(1):121-161. 
Constable, N. (2005) Introduction: Cross-border marriages, gendered mobility and global hypergamy. In Constable, N. (ed.) Cross-border marriages: Gender and mobility in transnational Asia, pp. 1-16. Philadelphia: University of Pennsylvania Press.

Dasgupta, S.D. and Rudra, U. (2009) Transnational Abandonment of South Asian Women: A New Face of Violence against Women. Manavi Occasional Paper. New Jersey, USA.

Dube, L. (2001) Anthropological explorations in gender. New Delhi: Sage.

Fernandez, M. (1997) Domestic violence by extended family members in India: Interplay of gender and generation. Journal of Interpersonal Violence 12(3), 433-455.

Gangoli, G. and Rew, M. (2011) Mothers-in-laws against daughters-in-laws: Domestic violence and legal discourses around mother-in-law violence against daughters-in-law in India, Women’s Studies International Forum 34, 420-429.

Gupta, M. D. (2016). Govt will help women trapped in abusive marriages to NRI men. The Hindustan Times, July 06. Available at: http://www.hindustantimes.com/india-news/govt-willhelp-women-trapped-in-abusive-marriages-to-nri-men-maneka/story-

q6BfuIfJFSBUHTsVOze4oM.html (accessed 7 December 2017)

Hester, M. (2009) Who Does What to Whom? Gender and Domestic Violence Perpetrators, Bristol: University of Bristol in association with the Northern Rock Foundation.

Jabbi, M. (2005) A Diagnostic study of wives deserted by NRIs. New Delhi: Council for Social Development.

Jaising, I. (2009). Bringing rights home: Review of the campaign for a law on domestic violence. Economic and Political Weekly, 50-57.

Jones, R. (2017) ‘Once a girl is married, there is no going back’, ABC News, 29 July. Available at: $\quad$ http://www.abc.net.au/news/2017-07-29/dowry-abuse-domestic-violence-kasishstory/8745118 (accessed 7 December 2017)

Kandiyoti, D. (1988) Bargaining with patriarchy, Gender and Society 2: 274-290. 
Kapur, R and Crossman, B. (1996) Subversive Sites: Feminist engagement with law in India. New Delhi, Sage.

Kelly, L. (1988) Surviving sexual violence. Cambridge: Polity Press.

Kelly, L. (2016) 'The conducive context of violence against women and girls', Discover

Society, issue 30. Available at: https://discoversociety.org/2016/03/01/theorising-violenceagainst-women-and-girls/ (accessed 20 February 2018).

Lawyers Collective. (2012). Staying Alive 5th Monitoring \& Evaluation 2012 on the Protection of Women from Domestic Violence Act, 2005, Delhi, Lawyers Collective Women Rights Initiative. Available at:

http://www.unwomen.org//media/headquarters/media/stories/en/finalstayingalivelawyerscolle ctive1pdf.pdf?la=en\&vs=1033 (Accessed January 22 2018).

Mahler, S.J. and Pessar, P.R (2001) Gendered geographies of power: Analysing gender across transnational spaces, Identities 7(4), 441-459.

McVeigh, K. (2018) Abusive men 'using immigration fears to control women', The Guardian, 2 May 2018. Available at: https://www.theguardian.com/society/2018/may/02/abusive-menusing-uk-immigration-fears-to-control-women (Accessed 4 May 2018)

Menski, W. (1998) South Asians and the dowry problem. London: Trentham Books.

Mooney, N. (2006). Aspiration, reunification and gender transformation in Jat Sikh marriages from India to Canada. Global networks, 6(4), 389-403.

NCW (undated) Problems relating to NRI marriages: Dos and don'ts. Delhi: National Commission for Women and Ministry of Overseas Indian Affairs. Available at: http://ncw.nic.in/pdffiles/nridodont.pdf (Accessed 8 January 2018)

Palriwala, R. and Uberoi, P. (2008) Exploring the Links: Gender Issues in Marriage and Migration. In Palriwala, R. and Uberoi, P. (eds.) Marriage, migration and gender, pp. 23-60. New Delhi: Sage. 
Panchanadeswaran, S. and Koverola, C. (2005) The voices of battered women in India. Violence Against women 11(6):736-758.

Patel, P., Handa, R., Anitha, S. and Jahangir, S. (2016) Emerging issues for international family law, Part 3: Transnational marriage abandonment and the dowry question. Family Law Journal 46(12): 1443-1449.

Ragavan, M. and Iyengar, K. (2017) Violence Perpetrated by Mothers-in-Law in Northern India: Perceived Frequency, Acceptability, and Options for Survivors, Journal of Interpersonal Violence. Online first

Rastogi, M and Therly, P. (2006) Dowry and its link to violence against women in India: Feminist psychological perspectives. Trauma, Violence \& Abuse 7: 66-77.

Riessman, C. (2008). Narrative Methods for the Human Sciences. California: Sage.

Sheel, R. (2005) Marriage, money and gender: A case study of migrant Indian community in Canada, Indian Journal of Gender Studies 12 (2 \&3):335-356.

Sen, A. (2003) Missing women -revisited. British Medical Journal 327, 1297-98.

Srinivasan, S. and Bedi, A.S. (2007) Domestic violence and dowry: Evidence from a South Indian village. World Development, 35: 857-880.

Stark, E. (2007) Coercive Control: The entrapment of women in personal life, New York: Oxford University Press.

Voigt-Graf, C. (2004) Towards a geography of transnational spaces: Indian transnational communities in Australia, Global Networks 4(1), 25-49.

Waheed, A. (2009)_Dowry among Indian Muslims: Ideals and Practices, Indian Journal of Gender Studies 16(1), 47-75.

Walton-Roberts, M. (2003) Transnational geographies: Indian immigration to Canada, The Canadian Geographer 47(3), 235-250. 